\title{
Empirical Model Valuation of Urban Agriculture Vulnerability to Flooding in Makurdi, Benue State, Nigeria
}

\author{
J. J Kunda ${ }^{1}$, Ahmed Abubakar Jajere ${ }^{2}$, Otabe E. A. ${ }^{3}$, Chindo Musa Muhammed ${ }^{4}$, Umar Muhammed Bibi ${ }^{2}$ \& \\ Yusuf Maina-Bukar ${ }^{5}$ \\ ${ }^{1}$ School of Geography, University of Nottingham, Nottingham, United Kingdom \\ ${ }^{2}$ Department of Geography, Federal University Kashere, Gombe, Nigeria \\ ${ }^{3}$ Department of Geography, Nasarawa State University, Keffi, Nigeria \\ ${ }^{4}$ Faculty of Built Environment \& Surveying, Universiti Teknologi Malaysia, Malaysia \\ ${ }^{5}$ Desert Research, Monitoring and Control Centre (DRMCC), Yobe State University, Damaturu, Nigeria \\ Correspondence: J. J Kunda, School of Geography, University of Nottingham, Nottingham NG7 2RD, United \\ Kingdom. Tel: 234-80-3663-3727. E-mail: jonahkunda@yahoo.com
}

Received: March 27, 2021

doi:10.5539/ep.v10n2p20
Accepted: May 30, $2021 \quad$ Online Published: June 3, 2021

URL: https://doi.org/10.5539/ep.v10n2p20

\begin{abstract}
For this study, geospatial technology was used to assess agricultural lands vulnerable to flooding in Makurdi, Benue State, Nigeria. Six thematic layers of factors influencing flood occurrences in the study area were generated from monthly rainfall, land use/cover, drainage density, soil, digital elevation model and slope. Pairwise comparison of the Analytical Hierarchy Process was used to derive the weights for each factor using expert's judgements and literature. Weighted overlay model from the spatial analysis tool in the ArcGIS 10.4 environment was used to perform the vulnerability modelling. Expert's judgement on the relative factors influencing flood in the study area was: rainfall (25\%), elevation (22\%), slope (20\%), drainage density $(13 \%)$, soil type $(8 \%)$ and land use/cover $(12 \%)$. The consistency ratio of the analysis was reasonable: $(\mathrm{CR}=0.078)$. Results from the model demonstrated land vulnerability to urban agricultural flooding in the study area ranging from areas of very highly vulnerable to very low vulnerable areas, with farmlands along the floodplains of River Benue falls within the very highly vulnerable areas. The elements at Risk are; Farmland 537.6 (66.1\%), Irrigation Land 40.5 (5.0\%) and Builtup Land 125.8 (15.5\%).
\end{abstract}

Keywords: geospatial technology, flooding, urban agriculture, Makurdi town

\section{Introduction}

Flooding refers to a condition in which a dry land area is covered by water resulting from excessive rainfall, overflow of rivers/dams, the dam burst, blockade of waterways, earthquake/tsunamis, high tide and protective release of water from dams (Ologunorisa, 2004). Flooding is a temporary condition of partial or complete inundation of normally dry areas from overflow of inland/tidal waters or unusual and rapid accumulation/runoff (Jeb and Aggarwal, 2008; Xiong et al. 2019). The effects of natural hazards such as floods can be felt at the micro and macro levels, affecting communities, neighbourhood, drainage basins and large sparse of land (Mwangi, 2016; Rimba et al., 2017). Climate change and variability from anthropogenic activities have significant influences the elements of weather and climate comprising heavy and concentrated precipitations; environmental woes consisting of indiscriminate disposal of refuse in drainages and waterways, bush burning and destruction of vegetal cover, excessive cultivation and grazing activities are among the factors intensifying the occurrence of flooding in globally (Rogelj et al., 2012; IPCC, 2013; Kriegler et al., 2013).

Flood is a major threat to urban agriculture, food production, food prices, and the nutritive and microbial quality of harvested food materials. It is the critical driver of food insecurity and malnutrition that induces migration and community conflict, which prejudices the capability of the government to function effectively in the affected areas (Lynch et al., 2001; De Zeeuw et al., 2001). Among the significant effects of the flood on human health are their chemical injury and the worsening of water-borne diseases such as typhoid fever, cholera, leptospirosis, and hepatitis. Flood has a significant influence on vector-borne diseases, including malaria, dengue, yellow fever, and West Nile fever (WHO, 2001; Tapsell et al., 2012; Munro et al., 2017; Paavola, 2017). Paterson et al. (2018) 
emphasized the high incidences of diseases, such as influenza, tuberculosis, typhoid fever, dysentery and malaria, and higher health expenditures among fishers during flooding periods.

Flood is among the most devastating natural disaster in Nigeria since the 1980s (Ologunorisa, 2004; Egbinola et al., 2017; Ajaero, 2017). The 2012 floods in Nigeria affected 27.9\% of yam, $21.6 \%$ of cassava, $17.2 \%$ of sweet potato, $31.4 \%$ of rice, $20.1 \%$ of maize, and $14 \%$ of sorghum-producing areas of Benue Trough (Ade, 2018). One of the significant effects of the flood on farming communities and farmers is the decline in environmental quality, an outbreak of diseases, crop failure, and damage of seeds and loss of livestock (Chowdhury and Hassan, 2017). These impacts together have resulted in rural-urban migration in many communities, leading to a decline in agricultural labour, reduction in food production and decrease in household income, which trigger hunger and starvation (Brouwer et al., 2007; Highfield and Brody, 2017). This study aimed to valuate urban Agriculture vulnerability to flooding in Makurdi, Benue State, Nigeria. As the Nation's food basket, Benue state is the major sources of yams, sorghum, millet, rice, cassava, shea nuts, sesame oil, peanuts (groundnuts), soybeans, and cotton to other parts of Nigeria. These agricultural products were grown by the Tiv, Idoma, Igede and other minorities' settlers (Okwu and Daudu 2011; Age et al. 2012; Ugbidye et al. 2020). Over the recent years, flood disaster among farm families in Benue State, Nigeria is a recurrent annual event with implication on food security, high level of poverty, low levels of human and physical capital, and poor infrastructure (Mbah et al. 2020). The IPCC (2017) projected a decline in crop yields in sub-Saharan Africa by 2050, this will lead to the vast number of now poor people who depend on farming for their incomes deeper into poverty, with a decline in food availability by 500 calories less $(21 \%$ decline) per person and a further increase in the number of malnourished children by over 10 million.

Flood vulnerability mapping is a vital component of flood mitigation measures and land use planning. The advances in geospatial technologies comprising Global Positioning System (GPS), Remote Sensing (RS) and Geographic Information Systems (GIS) has enabled the acquisition, assembling, storing, manipulating, analysis and display of geospatial data for defining areas vulnerable to flood in the form of maps. These maps are accurate and suitable tools for a timely mitigation process (Ouma and Tateishi, 2014; Darabi et al., 2019). GIS technique is a suitable tool that facilitates the integration of data sets of rainfall, soil, topography, land use, drainage, and catchment flows to map flood vulnerable areas. The flood vulnerability maps are vital tools for flood assessment, mitigation, planning and control (Ayeni, 1998; Szewrański et al., 2018; Sarkar and Mondal 2020). This study assesses urban agricultural lands vulnerable to flooding in Makurdi, Benue State, Nigeria, using geospatial technology.

\section{The Study Area}

Makurdi LGA is a location within latitude $7^{\circ} 36^{\prime} \mathrm{N}$ and $7^{\circ} 50^{\prime} \mathrm{N}$; and Longitudes $8^{\circ} 23^{\prime} \mathrm{E}$ and $8^{\circ} 38^{\prime} \mathrm{E}$. The area covers a radius of $16 \mathrm{Km} 2$ with an area of about $800 \mathrm{~km}$ and transversed by the second largest river in the country, the river Benue on the plain of Benue Trough. The area is situated in the middle belt region of North Central Nigeria on a transit/nodal point (rail, road and inland waterways) between the southeast and northern parts of Nigeria (Clement, 2012). Makurdi LGA falls within the transitional belt from the densely vegetated southeastern Nigeria to northern Nigeria's Guinea and Sudan region. According to the National Population Commission (2007), the 2006 population census recorded the population of Makurdi as 297, 398, with an average elevation that ranges between $250 \mathrm{~m}-450 \mathrm{~m}$ above sea level (Shabu and Tyonum, 2013). The study area is composed of sedimentary rocks which have undergone varying degrees of metamorphism. These sedimentary materials are underline at variable depths by the basement complex rock, which sandstone is the dominant rock type. The climate of the area is tropical sub-humid with two district seasons. The wet season starts in April and ends in October. It is characterized by maritime air mass from the Atlantic ocean, with a mean annual rainfall of $1,701 \mathrm{~mm}$ (Abah and Petja, 2016). The dry season starts from November and extends to march, characterized by continental northeast trade winds from the Sahara desert (Adeoye et al., 2009). Figure 1 presents the study area map. 


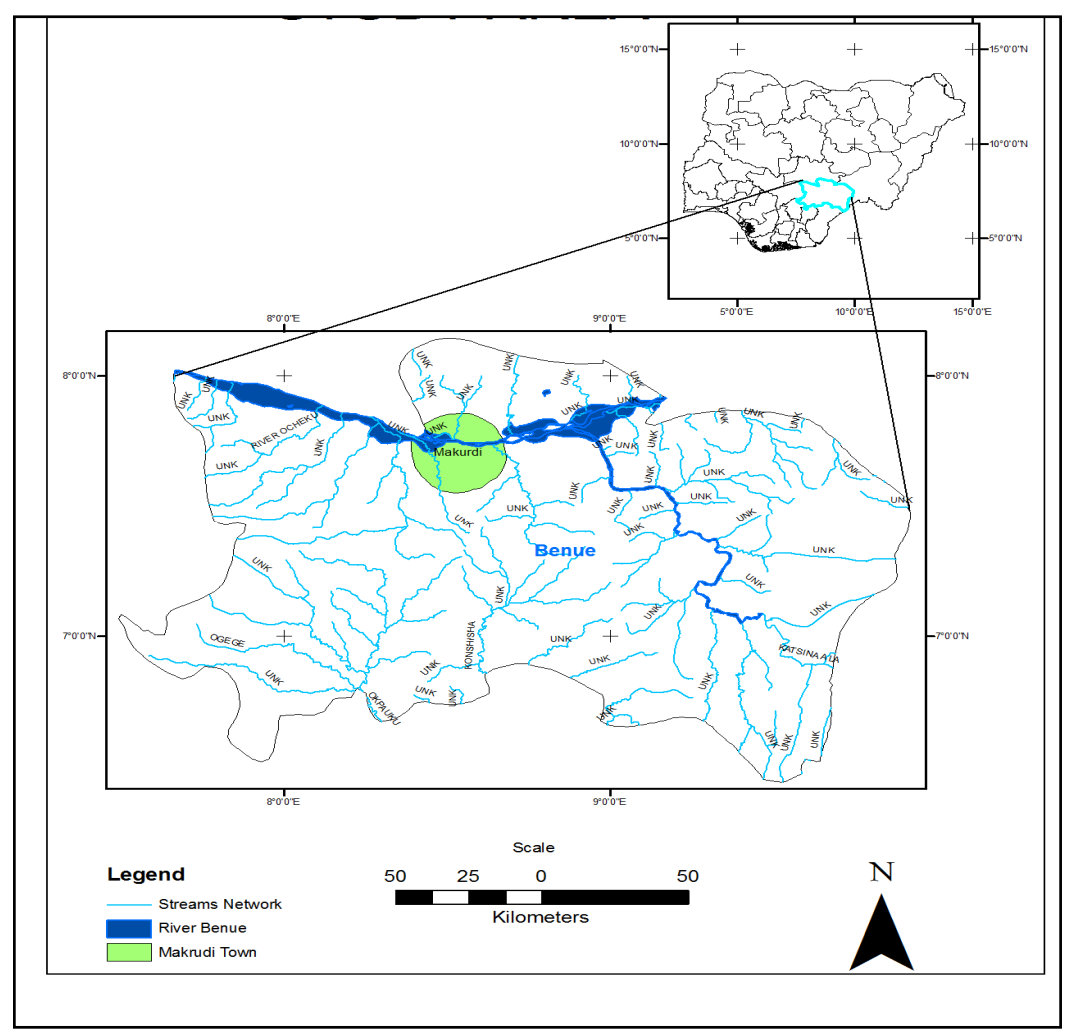

Figure 1. The study area

\section{Materials and Methods}

Table 1. Type and sources of data for the study

\begin{tabular}{|c|c|c|c|c|}
\hline Data Type & Resolution/Scale & Source(s) & $\begin{array}{l}\text { Date } \\
\text { Acquired }\end{array}$ & Relevance \\
\hline Landsat 8 & 30 & $\begin{array}{l}\text { United States Geological Survey } \\
\text { (USGS) www.glovis.usgs.gov }\end{array}$ & 2018 & $\begin{array}{l}\text { Generating } \\
\text { use/cover layer }\end{array}$ \\
\hline Topographic map & $1: 100,000$ & $\begin{array}{l}\text { Office of the Surveyor General of } \\
\text { the Federation }\end{array}$ & 1966 & $\begin{array}{l}\text { Generation of Drainage } \\
\text { Density layer }\end{array}$ \\
\hline Soil Map & $1: 650.000$ & $\begin{array}{l}\text { Department of Soil Science, } \\
\text { Ahmadu Bello Univ., Zaria }\end{array}$ & 1990 & Generation of Soil layer \\
\hline Rainfall data & $\begin{array}{l}\text { years } \\
2017)\end{array}$ & Nigerian Meteorological Agency & 2017 & $\begin{array}{l}\text { Generation of Rainfall } \\
\text { layer }\end{array}$ \\
\hline ASTER data & $30 \mathrm{~m}$ & $\begin{array}{l}\text { United States Geological Survey } \\
\text { (USGS) www.glovis.usgs.gov }\end{array}$ & 2018 & $\begin{array}{l}\text { Generation of Slope and } \\
\text { Elevation layers }\end{array}$ \\
\hline $\begin{array}{l}\text { Coordinates } \\
\text { Facilities }\end{array}$ & ---- & GPS collections & $\begin{array}{l}\text { September, } \\
2018\end{array}$ & $\begin{array}{l}\text { Determining } \\
\text { vulnerability status of } \\
\text { facilities }\end{array}$ \\
\hline $\begin{array}{l}\text { Point location } \\
\text { (Coordinates) of } \\
\text { localities }\end{array}$ & ---- & Upstate Office & 2018 & $\begin{array}{l}\text { Used to determine the } \\
\text { vulnerability status of } \\
\text { localities }\end{array}$ \\
\hline $\begin{array}{l}\text { Population data by } \\
\text { locality }\end{array}$ & ---- & NPC State Office & 1996 & $\begin{array}{l}\text { Used to determine the } \\
\text { population at risk }\end{array}$ \\
\hline
\end{tabular}




\subsection{Data Processing}

\subsubsection{Preparation of Thematic Layers}

As part of the data preparation, the Area of Interest (AOI) for this study was created and all the datasets were submapped to the (AOI) in ArcGIS 10.4 environment. Thematic maps were produced for all six factors influencing flood occurrence in the study area. The six thematic layers used as flood indicators for this study, including land use/cover, drainage density, soil, rainfall, elevation, and slope, were converted to raster data sets with the same pixel size. The datasets were reclassified based on their relative influence to flood. The reclassification of the thematic layers was performed based on the expert's judgements on the relative influence of the thematic layers to flood. Pairwise comparison was used to weight the thematic layers, which were compared with each other for weighted overlay operation.

\subsection{Deriving the Criterion weights using Analytic Hierarchical Process (AHP)}

The relative influence of the flood indicators and their attributes were analyzed using AHP. The following steps were involved: Step 1: Clearly defining the problem into thematic layers containing feature of the individual themes to form a network of the model. Step 2: Generating Pair-wise Comparison Matrices: The relative influence values are determined with Saaty's 1-9 scale (Table 2), where a score of 1 represents equal importance between the two attributes, and a score of 9 indicates the extreme importance of one attribute compared to the other one (Saaty, 1980).

Table 2. Fundamental scale for pair wise comparison (Source: Saaty, 1980)

\begin{tabular}{lll}
\hline $\begin{array}{l}\text { Intensity of } \\
\text { Importance }\end{array}$ & Definition & Explanation \\
\hline $\mathbf{1}$ & Equal importance & \\
$\mathbf{3}$ & Moderate importance & $\begin{array}{l}\text { Two elements contribute equally to the objective } \\
\text { Experience and judgment slightly favour one element over } \\
\text { another }\end{array}$ \\
$\mathbf{5}$ & Strong importance & $\begin{array}{l}\text { Experience and judgment strongly favour one element over } \\
\text { another }\end{array}$ \\
$\mathbf{7}$ & Very Strong importance & $\begin{array}{l}\text { One element is favoured very strongly over another; its } \\
\text { dominance is demonstrated in practice }\end{array}$ \\
& & The evidence favouring one element over another is of the \\
& Extreme importance & \\
& $2,4,6$, and 8 are intermediate & \\
& values &
\end{tabular}

A pairwise comparison matrix was derived using Saaty's nine-point importance scale. The AHP captures the idea of uncertainty in judgments' through the consistency index (Saaty, 2004). The measure of consistency is as follows:

- Consistency Ratio (CR) is a measure of the consistency of judgment amongst the criteria.

- The rule of thumb states that the CR should be less than or equal to 0.1

- Thus, a value of 0-0.1 is accepted in practice.

- Any higher value indicates that the judgment warrant re-visitation

- $\mathrm{CR}$ thus is evaluated as follows: $\mathrm{CR}=\mathrm{CI} / \mathrm{RI}$ where

CI- represents Consistency Index which reflects the consistency of one's judgment

$\mathrm{CI}=\lambda \max -\mathrm{n} / 1-\mathrm{n}$; and $\lambda$ is calculated by averaging the value of the consistency vector (calculated factor weight), RI- denotes Random Inconsistency index dependent on the sample size as shown in Table 3. 
Table 3. Random Inconsistency Indices (RI) for N-10 (Source: Saaty, 1980)

\begin{tabular}{lllllllllll}
\hline $\mathrm{n}$ & 1 & 2 & 3 & 4 & 5 & 6 & 7 & 8 & 9 & 10 \\
\hline $\mathrm{RI}$ & 0 & 0 & 0.58 & 0.89 & 1.12 & 1.24 & 1.32 & 1.41 & 1.45 & 1.49 \\
\hline
\end{tabular}

\section{Thematic layer Integration}

All the weighted data sets were integrated into ArcGIS 10.4 to produce the flood vulnerability map by a weighted overlay. Each class individual's weight was multiplied by the map scores, and the results added. The equation facilitates this procedure:

$$
\mathrm{S}=\sum \mathrm{Wi} \mathrm{Xi}
$$

Where; S = Vulnerability

$\mathrm{Wi}=$ Weight for each map

$\mathrm{Xi}=$ Individual map 


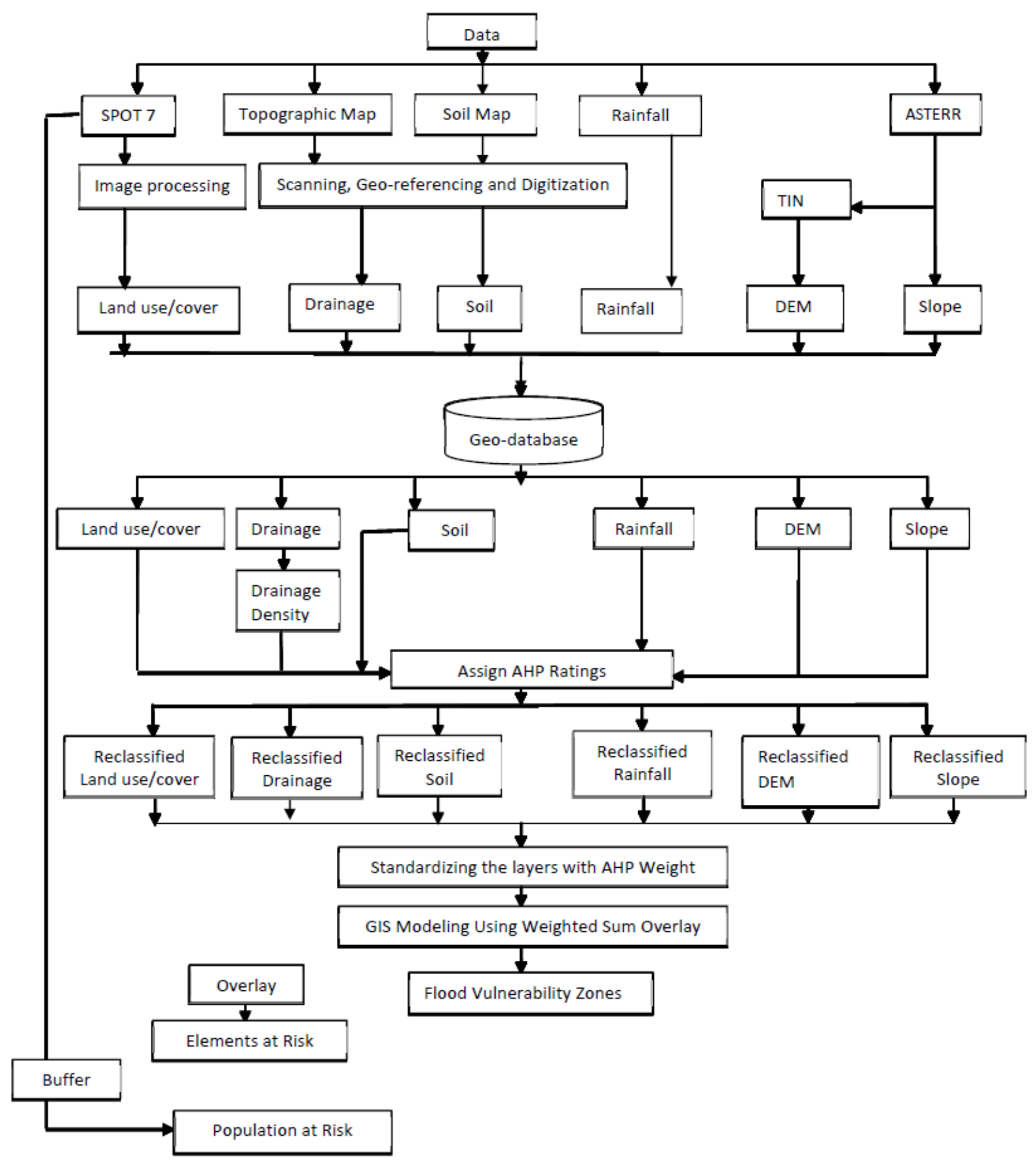

Figure 2. Methodology flow diagram

\section{Results and the Discussion}

\section{Factors Influencing Floods}

The flood indicators considered in this study are rainfall, elevation, slope, soil, drainage density and land cover.

\section{Rainfall and Slope}

For this study area, Agan and North bank parts of the Federal University of Agriculture experience deficient rainfall between 1,576-1,601 mm and 1,602-1,621 mm. Gurukul, Angwan Jukun, Rice mill, Old Gra, Wadata, Modern Market, and High-level experience moderate rainfall (1,622-1,643mm) Hudco quarters, Commissioners village, Airport have high rainfall with an annual range of $1,644-1667 \mathrm{~mm}$. Rainfall is at its peak at New GRA, 
Kanshio, with an annual range of $1,668-1,701 \mathrm{~mm}$. The slope of the study area ranges between 0 to $56 \%$. This implies that flat areas with a gentle slope can hold rainfall, which facilitates the accumulation of water on the surface. An elevated area where the slope is steep has high chances of runoff and low accumulation, as presented in figure 3 and table 4.
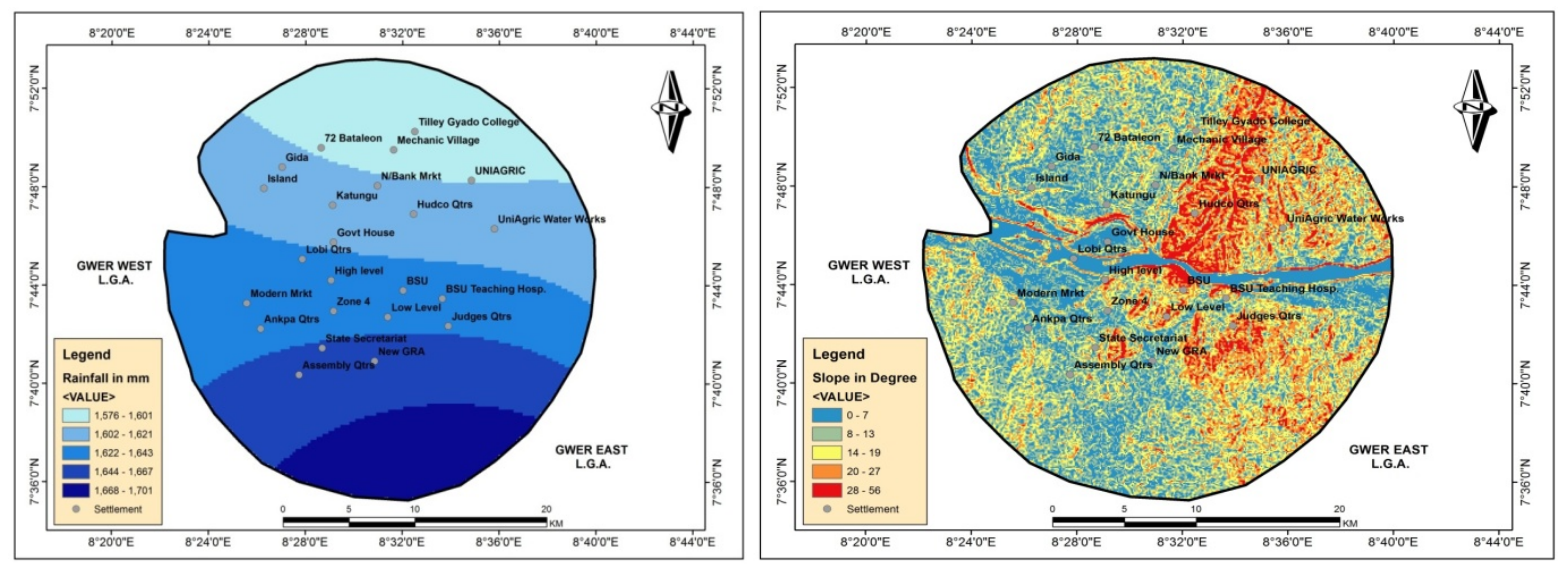

Figure 3. Rainfall and slope of the study area

Table 4. Weights and reclassified rainfall of the area

\begin{tabular}{lccccllll}
\hline Factor & 1,576 & $-1,602$ & $-1,622$ & $-1,644-1,667$ & $1,668-1,701$ & Weight & Vulnerability \\
& 1,601 & 1,621 & 1,643 & & & & \\
\hline $1,576-1,601$ & 1 & 2 & 4 & 6 & 8 & 4 & Very Low \\
$1,602-1,621$ & $1 / 2$ & 1 & 2 & 4 & 6 & 8 & Low \\
$1,622-1,643$ & $1 / 4$ & $1 / 2$ & 1 & 2 & 4 & 14 & Moderate \\
$1,644-1,667$ & $1 / 6$ & $1 / 4$ & $1 / 2$ & 1 & 2 & 27 & High \\
$1,668-1,701$ & $1 / 8$ & $1 / 6$ & $1 / 4$ & $1 / 2$ & 1 & 47 & Very High \\
\hline
\end{tabular}

Consistency Ratio $=0.058$

Table 5. Weights and reclassified slope of the study area

\begin{tabular}{lllllllll}
\hline Factor & $\mathbf{0 - 7}$ & $\mathbf{8 - 1 3}$ & $\mathbf{1 4} \mathbf{- 1 9}$ & $\mathbf{2 0 - 2 7}$ & $\mathbf{2 8 - 5 6}$ & Weight & Weight*100 & Vulnerability \\
\hline $\mathbf{0 - 7}$ & 1 & $9 / 7$ & $9 / 5$ & 3 & 9 & 0.362 & 36 & Very High \\
$\mathbf{8 - 1 3}$ & $7 / 9$ & 1 & $7 / 5$ & $7 / 3$ & 7 & 0.284 & 28 & High \\
$\mathbf{1 4} \mathbf{- 1 9}$ & $5 / 9$ & $5 / 7$ & 1 & $5 / 3$ & 5 & 0.202 & 20 & Moderate \\
$\mathbf{2 0 - 2 7}$ & $1 / 3$ & $3 / 7$ & $3 / 5$ & 1 & 3 & 0.116 & 12 & Low \\
$\mathbf{2 8 - 5 6}$ & $1 / 9$ & $1 / 7$ & $1 / 5$ & $1 / 3$ & 1 & 0.038 & 4 & Very Low \\
\hline
\end{tabular}

Consistency Ratio $=0.06$

With a consistency ratio $(\mathrm{CR})$ of 0.06 , the judgment was seen to be consistent. According to Lindsay-Walters (2015), the topography of the drainage basin can affect the speed with which the precipitation flows: with a great angle, it will be faster, and with a more obtuse angle, it will be slower due to the effects of gravity, in other words, the steeper the basin, the more quickly it drains and vice versa. The pairwise comparison carried out, and weights calculated in Table 5 for slope angle was based on the fact that the flatter the topography (low slope angle), the greater the chances for water to accumulate on the surface and vice versa. 

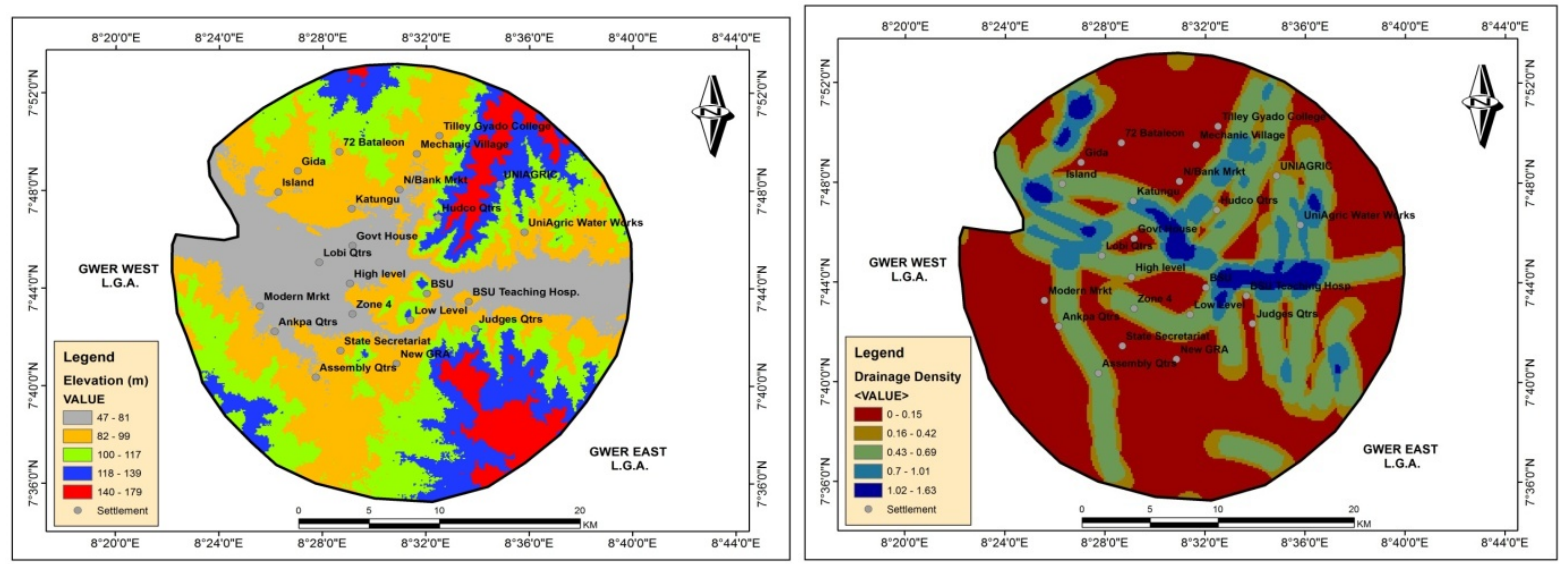

Figure 4. Elevation and drainage density of the study area

Table 6. Weight for elevation

\begin{tabular}{llllllll}
\hline Factor & $\mathbf{4 7 - 8 1}$ & $\mathbf{8 2 - 9 9}$ & $\mathbf{1 0 0 - 1 1 7}$ & $\mathbf{1 1 8 - 1 3 9}$ & $\mathbf{1 4 0 - 1 7 9}$ & Weightage & Vulnerability \\
\hline $\mathbf{4 7 - 8 1}$ & $\mathbf{1}$ & $1 / 2$ & $1 / 2$ & $1 / 2$ & $1 / 2$ & 0.32 & Very High \\
$\mathbf{8 2 - 9 9}$ & 2 & $\mathbf{1}$ & $1 / 2$ & $1 / 2$ & $1 / 2$ & 0.24 & High \\
$\mathbf{1 0 0 - 1 1 7}$ & 2 & 2 & $\mathbf{1}$ & $1 / 2$ & $1 / 2$ & 0.19 & Moderate \\
$\mathbf{1 1 8 - 1 3 9}$ & 2 & 2 & 2 & $\mathbf{1}$ & $1 / 2$ & 0.14 & Low \\
$\mathbf{1 4 0 - 1 7 9}$ & 2 & 2 & 2 & 2 & $\mathbf{1}$ & 0.11 & Very Low \\
\hline
\end{tabular}

Consistency Ratio $=0.01$

The pairwise comparison for elevation (Table 6) was based on the fact that areas on low elevations lying adjacent to the rivers are prone to flood while those on high elevations are less prone. It can be seen from the Table that areas with low elevation value are rated very high, which implies very high flood vulnerability and vice versa. In other words, areas with low elevation can easily get flooded than those found on the high elevation even though they can be categorized as being on low elevations.

Table 7. Weight for drainage density

\begin{tabular}{lllllllll}
\hline Factor & $\mathbf{0 - 0 . 1 5}$ & $\mathbf{0 . 1 6 - 0 . 4 2}$ & $\mathbf{0 . 4 3 - 0 . 6 9}$ & $\mathbf{0 . 7 0 - 1 . 0 1}$ & $\mathbf{1 . 0 2 - 1 . 6 3}$ & Weight & Weight*100 & Vulnerability \\
\hline $\mathbf{0 - 0 . 1 5}$ & 1 & $1 / 7$ & 15 & $1 / 3$ & 1 & 0.038 & 4 & Very Low \\
$\mathbf{0 . 1 6 - 0 . 4 2}$ & $1 / 9$ & 1 & $3 / 5$ & $5 / 3$ & 3 & 0.116 & 12 & Low \\
$\mathbf{0 . 4 3 - 0 . 6 9}$ & $1 / 3$ & $3 / 7$ & 1 & $7 / 3$ & 5 & 0.20 & 20 & Moderate \\
$\mathbf{0 . 7 0 - 1 . 0 1}$ & $5 / 9$ & $5 / 7$ & 75 & 1 & 7 & 0.29 & 29 & High \\
$\mathbf{1 . 0 2 - 1 . 6 3}$ & $7 / 9$ & $9 / 7$ & $9 / 5$ & 3 & 9 & 0.36 & 36 & Very High \\
\hline
\end{tabular}

Consistency Ratio $=0.06$

Drainage density has been recognized by Pallard et al. (2009) to be significantly effective in the formation of flood flows. According to the author, high drainage densities can indicate a more significant flood risk, while a decreasing drainage density generally implies decreasing flood volumes. Thus, the five classes of drainage density generated from Figure 4 were compared against each other (Table 7). The pairwise comparison done for drainage density revealed that for areas with very low and low drainage densities, weights of 4 and 12 were calculated, respectively, while high and high drainage densities had high weights of 29 and 36, respectively. 


\section{Soil and land use/cover}

The soil map generated by digitizing the existing map of the study area. The different soil categories were identified and included sandy clay and loamy. According to FDALR (1990), sandy soil is moderately poorly drained while loamy sand, on the other hand, is well-drained.
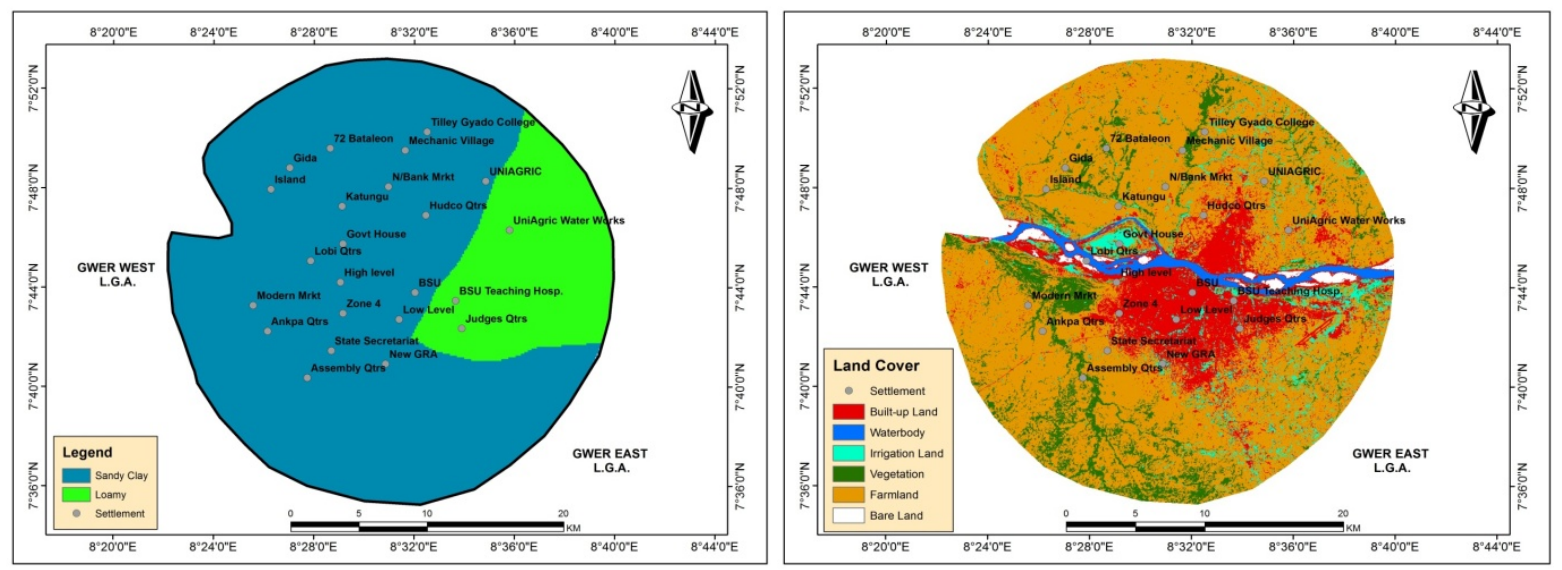

Figure 5. Elevation and drainage density of the study area

Table 8. Weight for soil

\begin{tabular}{llllll}
\hline Factor & Sandy Clay & Loamy & Weight & Weight*100 & Vulnerability \\
\hline Sandy Clay & 1 & $9 / 5$ & 0.64 & 64 & Moderately poorly drained (High) \\
Loamy & $5 / 9$ & 1 & 0.357 & 36 & Well Drained (Low) \\
\hline
\end{tabular}

Consistency Ratio $=0.1$

Table 9. Weight for land cover

\begin{tabular}{lllllllll}
\hline Factor & Built-up & Irrigation & Farmland & Bare land & Vegetation & $\begin{array}{l}\text { water } \\
\text { body }\end{array}$ & Weight & Weight*100 \\
\hline Built-up & 1 & $9 / 7$ & $9 / 5$ & $9 / 5$ & $9 / 3$ & $9 / 7$ & 0.24 & Extremely \\
& & & & & & & & High \\
Irrigation & $7 / 9$ & 1 & $7 / 5$ & $7 / 5$ & $7 / 3$ & 1 & 0.20 & Very High \\
Farmland & $7 / 9$ & 1 & $7 / 5$ & $7 / 5$ & $7 / 3$ & 1 & 0.18 & High \\
Bare land & $5 / 9$ & $3 / 7$ & 1 & 1 & $5 / 3$ & $5 / 7$ & 0.16 & Moderate \\
Vegetation & $5 / 9$ & $5 / 7$ & 1 & 1 & $5 / 3$ & $5 / 7$ & 0.14 & Low \\
water body & $3 / 9$ & $3 / 7$ & $3 / 5$ & $3 / 5$ & 1 & $3 / 7$ & 0.08 & Very Low \\
\hline
\end{tabular}

Consistency Ratio: 0.035

Classification of soil types was done based on their infiltration and water retention capacity, thereby reducing runoff or vice versa, as recognized by FDALR (1990). Sandy soils are moderately and poorly drained, and loamy soils are well-drained. This implies that sandy soils are more prone to flood than areas covered by loamy soils since their infiltration rate is poor. Table 8 shows the weights generated after pairwise comparison. Sandy soil has the highest weight of 64 while loamy sand has 36 .

The pairwise comparison carried out and weights calculated for land-cover (Table 9) was based on the fact that built-up areas and impervious surfaces generate more surface runoff since they do not allow infiltration, while others like vegetation comprising of forests and farmlands, on the other hand, permit interception of precipitation which can either evaporate and return to the hydrological cycle or flow down the stem of the plants and trees (stem 
flow) and then flow along the ground or infiltrate and percolate into the ground, thereby reducing the surface runoff and consequently the flood magnitude (Lindsay-Walters, 2015) as shown in figure 5 and table 9.

\section{Areas Vulnerable to Flooding}

The pairwise comparison carried out for the six flood causative factors (Table 10) was based on Saaty's Fundamental scale of pairwise comparison and the generated flood vulnerability map (Figure 6).

Table 10. Weight for all factor maps

\begin{tabular}{|c|c|c|c|c|c|c|c|c|}
\hline Factor & Elevation & Slope & LULC & $\begin{array}{l}\text { Drainage } \\
\text { Density }\end{array}$ & Rainfall & Soil & Weight & Weight*100 \\
\hline Rainfall & 1 & $9 / 7$ & $9 / 5$ & $9 / 5$ & $9 / 3$ & $9 / 7$ & 0.25 & 25 \\
\hline Elevation & $7 / 9$ & 1 & $7 / 5$ & $7 / 5$ & $7 / 3$ & 1 & 0.22 & 22 \\
\hline Slope & $7 / 9$ & 1 & $7 / 5$ & $7 / 5$ & $7 / 3$ & 1 & 0.20 & 20 \\
\hline $\begin{array}{l}\text { Drainage } \\
\text { density }\end{array}$ & $5 / 9$ & $3 / 7$ & 1 & 1 & $5 / 3$ & $5 / 7$ & 0.13 & 13 \\
\hline LULC & $5 / 9$ & $5 / 7$ & 1 & 1 & $5 / 3$ & $5 / 7$ & 0.12 & 12 \\
\hline Soil & $3 / 9$ & $3 / 7$ & $3 / 5$ & $3 / 5$ & 1 & $3 / 7$ & 0.08 & 8 \\
\hline
\end{tabular}

Consistency Ratio $=0.078$

The weights generated reveals that rainfall with 25 as its weight has the greatest influence on flood occurrences in the study area. Elevation and drainage density accounted for weights of 22 and 20 respectively, while drainage density 13, land cover 12 and soil the least with 8 . These factors were overlaid using the weighted sum in ArcGIS spatial tool to produce the flood vulnerability map as presented in Figure 6.

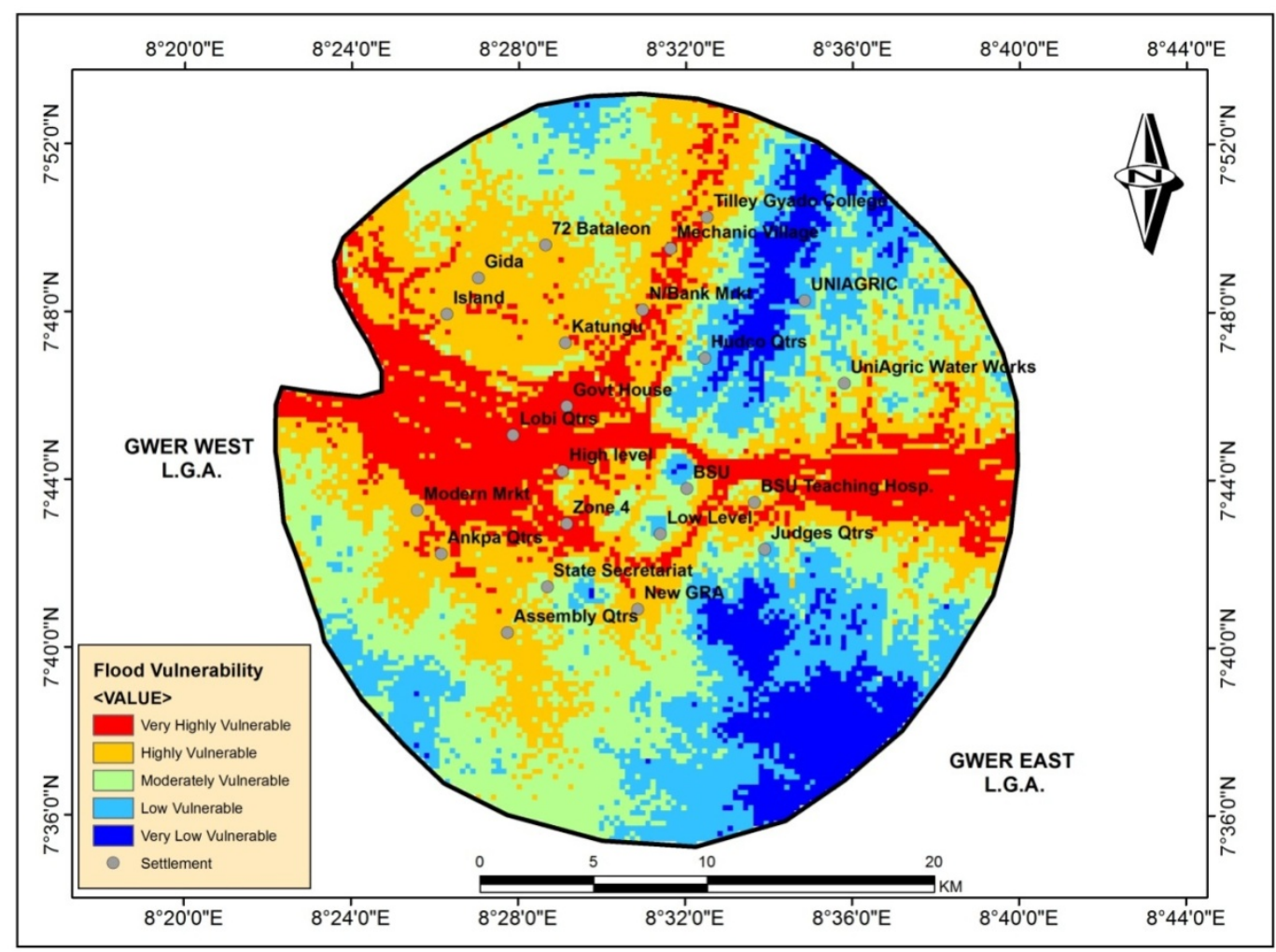

Figure 6. Flood vulnerability map of the study area 


\section{Conclusion}

Climate change and anthropogenic activities are the leading causes of flood which pose a serious problem to urban agriculture in Makurdi town, Benue State of Nigeria. The use of remotely sensed data and Geospatial techniques has proved a suitable combination of tools for flood modelling. The very high and high vulnerable areas of flood which were confirmed in Modern Market, Ankpa Quarters, BSU Teaching Hospital, Government House, Lobi Quarters, High Level, zone 4 and part of low level, among others parts of the study area are the flood-prone areas identified in the study. Flood in these areas is accompanied by loss of farm products, life and properties. It became necessary for the Government and policymakers, including stakeholders in disaster management, extension agencies, research institutions, meteorological institutes, disaster management agencies, higher institutions and local farmers, to improve farmers' access to flood education, seasonal flood forecasts and boost the processing machine capacity of farming. Timely accessibility of information on seasonal rainfall prediction will allow the farmers to know the precise onset, cessation and amount of rainfall that will be experienced in the season. This will help farmers in planning their coping strategies. More research using geospatial technology will assure a sustainable environment by improving farmers' accessibility to flood warning information, appropriate management of drainage channels, and the identifications of flood-prone areas to avoid cultivation in these areas. Besides, farmers should be encouraged to diversify their income-earning activities to flood-tolerant crops and invest in agro-allied occupations.

\section{References}

Abah, R. C., \& Petja, B. M. (2016). Assessment of potential impacts of climate change on agricultural development in the Lower Benue River Basin. Environmental monitoring and assessment, 188(12), 683. https://doi.org/10.1007/s10661-016-5700-x

Ade, M. A. (2018). The menace of Floods in the Benue Trough and Vulnerability Analysis: 2017 Flood. In Geophysical Research Abstracts (pp. 8-13).

Adeoye, N. O., Ayanlade, A., \& Babatimehin, O. (2009). Climate change and menace of floods in Nigerian cities: socio-economic implications. Advances in Natural and Applied Sciences, 3(3), 369-377.

Age, A. I., Obinne, C. P. O., \& Demenongu, T. S. (2012). Communication for sustainable rural and agricultural development in Benue State, Nigeria. Sustainable Agriculture Research, 1(1), 118. https://doi.org/10.5539/sar.v1n1p118

Ajaero, C. K. (2017). A gender perspective on the impact of flood on the food security of households in rural communities of Anambra state, Nigeria. Food Security, 9(4), 685-695. https://doi.org/10.1007/s12571-0170695-x

Ayeni, B. (1998). Principles of Geographic Information Systems (GIS). In Ayeni B. (Ed.), Geographic Information System and Environmental Monitoring. Workshop Proceedings (FEPA): University of Ibadan.

Balabanova, S., \& Vassilev, V. (2010). Creation of Flood Hazard Maps. Water Observation and Information System for Balkan Countries (BALWOIS) 2010. Ohrid, Republic of Macedonia.

Brouwer, R., Akter, S., Brander, L., \& Haque, E. (2007). Socioeconomic vulnerability and adaptation to environmental risk: a case study of climate change and flooding in Bangladesh. Risk Analysis: An International Journal, 27(2), 313-326. https://doi.org/10.1111/j.1539-6924.2007.00884.x

Chowdhury, E. H., \& Hassan, Q. K. (2017). Use of remote sensing data in comprehending an extremely unusual flooding event over Southwest Bangladesh. Natural Hazards, 88(3), 1805-1823. https://doi.org/10.1007/s11069-017-2947-7

Clement, A. R. (2012). Causes of seasonal flooding in flood plains: a case of Makurdi, Northern Nigeria. International journal of environmental studies, 69(6), 904-912. https://doi.org/10.1080/00207233.2012.730668

Darabi, H., Choubin, B., Rahmati, O., Haghighi, A. T., Pradhan, B., \& Kløve, B. (2019). Urban flood risk mapping using the GARP and QUEST models: A comparative study of machine learning techniques. Journal of hydrology, 569, 142-154. https://doi.org/10.1016/j.jhydrol.2018.12.002

De Zeeuw, H., Van Veenhuizen, R., \& Dubbeling, M. (2011). The role of urban agriculture in building resilient cities in developing countries. The Journal of Agricultural Science, 149(S1), 153-163. https://doi.org/10.1017/S0021859610001279

Egbinola, C. N., Olaniran, H. D., \& Amanambu, A. C. (2017). Flood management in cities of developing countries: 
the example of Ibadan, Nigeria. Journal of Flood Risk Management, 10(4), 546-554. https://doi.org/10.1111/jfr3.12157

European Commission (EC). (2007). Directive 2007/60/EC of the European Parliament and of the Council of 23 October, 2007 on the assessment and management of flood risks. Official Journal of the European Union, L288/27-34. Retrieved November $\quad 20, \quad$ from http://eurlex.europa.eu/LexUriServ/LexUriServ.do?uri=OJ:L:2007:288:0027:0034:EN:PDF

FAO. (1990). Guidelines for soil description (3rd ed.). Soil Resources, Management and Conservation Service, Land and Water Development Division. FAO, Rome. 70 pp.

FDALR. (1990). Soil map of Nigeria. Federal Department of Agricultural Land Resources, Abuja.

Highfield, W. E., \& Brody, S. D. (2017). Determining the effects of the FEMA Community Rating System program on flood losses in the United States. International journal of disaster risk reduction, 21, 396-404. https://doi.org/10.1016/j.ijdrr.2017.01.013

Inter-governmental Panel on Climate Change (IPCC, 2017). Climate Change 2017: Impacts, Adaptation Vulnerability. Contribution of Working Group II to the. Third Assessment Report of the Intergovernmental Panel on Climate Change. Geneva: UNEP/WMO.

IPCC. (2013). In T. F. Stocker, D. Qin, G.-K. Plattner, M. Tignor, S. K. Allen, J. Boschung, Climate change 2013: The physical science basis. Contribution of working group I to the fifth assessment report of the intergovernmental panel on climate change (p. 1535). Cambridge, United Kingdom and New York, NY, USA. Cambridge University Press. Retrieved from http://www.ipcc.ch/report/ar5/

Jeb, D. N., \& Aggarwal, S. P. (2008). Flood inundation hazard modelling of the River Kaduna using remote sensing and geographic information systems. Journal of Applied Sciences Research, 4(12), 1822-1833.

Jeyaseelan, A. T. (1999). Droughts and floods assessment and monitoring using remote sensing and GIS. Satellite Remote Sensing and GIS Applications in Agricultural Meteorology, 291-313.

Kriegler, E., O’Neill, B. C., Hallegatte, S., Kram, T., Lempert, R. J., Moss, R. H., \& Wilbanks, T. (2012). The need for and use of socio-economic scenarios for climate change analysis: a new approach based on shared socioeconomic pathways. Global Environmental Change, 22(4), 807-822. https://doi.org/10.1016/j.gloenvcha.2012.05.005

Lynch, K., Binns, T., \& Olofin, E. (2001). Urban agriculture under threat: The land security question in Kano, Nigeria. Cities, 18(3), 159-171. https://doi.org/10.1016/S0264-2751(01)00008-7

Mbah, E. N., Yanjoh, E. T., \& Iorhemba, S. T. (2020). Strategies for Coping with Food Insecurity during Flood Disaster among Farm Families in Benue State, Nigeria. Asian Journal of Advances in Agricultural Research, 39-46. https://doi.org/10.9734/ajaar/2020/v13i130097

Munro, A., Kovats, R. S., Rubin, G. J., Waite, T. D., Bone, A., Armstrong, B., \& Oliver, I. (2017). Effect of evacuation and displacement on the association between flooding and mental health outcomes: a crosssectional analysis of UK survey data. The lancet Planetary health, 1(4), e134-e141. https://doi.org/10.1016/S2542-5196(17)30047-5

Mwangi, M. P. (2016). The role of land use and land cover changes and GIS in flood risk mapping in Kilifi County, Kenya (Doctoral dissertation, Kenyatta University).

Nmeribeh, M. (2011). Kano's flood disaster. The NEWS. Retrieved October 25, 2011, from http://thenewsafrica.com/2011/06/27/kano\%E2\%80\%99s-flood-disaster/

Okwu, O. J., \& Daudu, S. (2011). Extension communication channels usage and preference by farmers in Benue State, Nigeria. Journal of Agricultural Extension and Rural Development, 3(5), 88-94.

Ologunorisa, T. E. (2004). An assessment of flood vulnerability zones in the Niger Delta, Nigeria. International journal of environmental studies, 61(1), 31-38. https://doi.org/10.1080/0020723032000130061

Ouma, Y., \& Tateishi, R. (2014). Urban flood vulnerability and risk mapping using integrated multi-parametric AHP and GIS: methodological overview and case study assessment. Water, 6(6), 1515-1545. https://doi.org/10.3390/w6061515

Paavola, J. (2017). Health impacts of climate change and health and social inequalities in the UK. Environmental Health, 16(1), 113. https://doi.org/10.1186/s12940-017-0328-z

Pallard, B., Castellarin, A., \& Montanari, A. (2009). A look at the links between drainage density and flood 
statistics. Hydrology and Earth System Sciences, 13(7), 1019-1029. https://oi.org/10.5194/hess-13-10192009

Paterson, D. L., Wright, H., \& Harris, P.N. (2018). Health risks of flood disasters. Clinical Infectious Diseases, 67(9), 1450-1454. https://doi.org/10.1093/cid/ciy227

Rimba, A. B., Setiawati, M. D., Sambah, A. B., \& Miura, F. (2017). Physical flood vulnerability mapping applying geospatial techniques in Okazaki City, Aichi Prefecture, Japan. Urban Science, 1(1), 7. https://doi.org/10.3390/urbansci1010007

Rogelj, J., Meinshausen, M., \& Knutti, R. (2012). Global warming under old and new scenarios using IPCC climate sensitivity range estimates. Nature climate change, 2(4), 248. https://doi.org/10.1038/nclimate1385

Saaty, T. L. (1980). Axiomatic foundation of the analytic hierarchy process. Management science, 32(7), 841-855. https://doi.org/10.1287/mnsc.32.7.841

Sarkar, D., \& Mondal, P. (2020). Flood vulnerability mapping using frequency ratio (FR) model: a case study on Kulik river basin, Indo-Bangladesh Barind region. Applied Water Science, 10(1), 1-13. https://doi.org/10.1007/s13201-019-1102-x

Shabu, T., \& Tyonum, T. E. (2013). Residents coping measures in flood prone areas of Makurdi Town, Benue State. Applied Ecology and Environmental Sciences, 1(6), 120-125. https://doi.org/10.12691/aees-1-6-4

Szewrański, S., Świąder, M., Kazak, J. K., Tokarczyk - Dorociak, K., \& Van Hoof, J. (2018). Socio environmental vulnerability mapping for environmental and flood resilience assessment: the case of ageing and poverty in the City of Wrocław, Poland. Integrated environmental assessment and management, 14(5), 592-597. https://doi.org/10.1002/ieam.4077

Tapsell, S. M., Penning-Rowsell, E. C., Tunstall, S. M., \& Wilson, T. L. (2002). Vulnerability to flooding: health and social dimensions. Philosophical transactions of the royal society of London. Series A: Mathematical, Physical and Engineering Sciences, 360(1796), 1511-1525. https://doi.org/10.1098/rsta.2002.1013

Ugbidye, S., Eneji, I. S., Wuana, R., \& Sha'Ato, R. (2020). Analysis of Mercury Levels in Agricultural Soils and Citrus Varieties from Benue State, Nigeria. Science Journal of Analytical Chemistry, 8(2), 65. https://doi.org/10.11648/j.sjac.20200802.15

World Health Organization. (2011). Use of glycated haemoglobin (HbAlc) in diagnosis of diabetes mellitus: abbreviated report of a WHO consultation (No. WHO/NMH/CHP/CPM/11.1). Geneva: World Health Organization.

Xiong, J., Li, J., Cheng, W., Wang, N., \& Guo, L. (2019). A GIS-based support vector machine model for flash flood vulnerability assessment and mapping in China. ISPRS International Journal of Geo-Information, 8(7), 297. https://doi.org/10.3390/ijgi8070297

\section{Copyrights}

Copyright for this article is retained by the author(s), with first publication rights granted to the journal.

This is an open-access article distributed under the terms and conditions of the Creative Commons Attribution license (http://creativecommons.org/licenses/by/4.0/). 